\title{
Different durations of whole raw soybean supplementation during the prepartum period: Milk fatty acid profile and oocyte and embryo quality of early-lactating Holstein cows
}

\author{
R. Gardinal,, ${ }^{*}$ G. D. Calomeni,, ${ }^{*}$ F. Zanferari, ${ }^{*}$ T. H. A. Vendramini, ${ }^{*}$ C. S. Takiya, ${ }^{\star}$ T. A. Del Valle, ${ }^{*}$ \\ and F. P. Renno* ${ }^{1}$ \\ *Department of Animal Nutrition and Production, University of Sao Paulo, Pirassununga, Brazil, 13635-900 \\ †Bursar 1-C of the National Council of Scientific and Technologic Development, Brasilia, Brazil, 716055-001
}

\section{ABSTRACT}

The objective of this study was to evaluate different durations of whole raw soybeans (WS) supplementation during the prepartum period on nutrient digestibility, milk yield and composition, energy balance, blood metabolites, and oocyte and embryo quality of transition cows. Thirty-one Holstein cows were used in a completely randomized design and assigned to 4 experimental groups (G): G90, G60, G30, and G0 (control), supplemented with a diet containing $12 \%$ of WS from $90,60,30$, and $0 \mathrm{~d}$ relative to the calving date, respectively. Cows were dried off $60 \mathrm{~d}$ before the expected calving date. After parturition, all cows were fed a diet containing $12 \%$ of WS until 84 DIM. Blood samples were collected on d $-49,-35,-21,-14,-7,0,7,14$, 21,35 , and 70 relative to partum. Ovum pick-ups were performed on d $21 \pm 3,42 \pm 7,63 \pm 7$, and $84 \pm 7$ of lactation. Different durations of WS supplementation did not affect DMI and apparent total-tract digestibility in either the pre- or postpartum periods. Duration of WS supplementation had no effect on milk yield and composition nor energy balance of cows. However, the duration of WS supplementation had several effects on milk fatty acid (FA) profile of cows, including a linear decrease in concentrations of cis-9 C18:1, unsaturated C18, total monounsaturated, and unsaturated FA. Further, the milk contents of cis-9,cis-12 C18:2 FA, cis-9,trans-11 C18:2 FA, and total polyunsaturated FA were increased when WS were fed to cows from $30 \mathrm{~d}$ but not from 60 or $90 \mathrm{~d}$ of the expected calving date. The length of WS supplementation in the prepartum period linearly increased blood cholesterol concentration of cows during the prepartum period, but it had no effect on blood glucose and nonesterified FA concentra-

Received December 21, 2016.

Accepted July 15, 2017.

${ }^{1}$ Corresponding author: francisco.renno@usp.br tions in the pre- and postpartum periods. Duration of WS supplementation during the prepartum period increased the average number of grade 2 oocytes, notably in G60, but it had no effect on embryo production and cleavage proportion of early-lactation cows. The duration of WS supplementation in the prepartum period had no effect on milk yield and energy balance of the subsequent lactation, but it altered milk FA profile in early lactation by decreasing unsaturated FA content, notably when starting to supplement WS at 90 and $60 \mathrm{~d}$ from the expected calving date. Our results also showed that the duration of WS supplementation during the prepartum period does not improve oocyte quality in the subsequent lactation of cows.

Key words: essential fatty acid, in vitro embryo production, linoleic acid, oilseed

\section{INTRODUCTION}

During the transition from 3 wk before parturition to 3 wk of lactation, several metabolic and hormonal changes occur that increase nutrient requirements to support milk production of fresh cows. However, DMI capacity lags behind energy requirements during early lactation, and so, the cow enters a state of negative energy balance (NEB). Negative energy balance is characterized by the mobilization of body reserves coupled with an increase of nonesterified fatty acids (NEFA) in an animal, which impair its reproductive function (Santos et al., 2008).

Supplying fatty acid (FA) sources to cows is a strategy to increase dietary energy density while minimizing NEB through the transition and early lactation. In addition, studies have demonstrated that UFA supplementation, particularly of n- 3 and n- 6 series, may influence the plasma FA amounts and profile, altering their availability in body tissues and benefiting animals' metabolism and health (Contreras and Sordillo, 2011). Whole raw soybean (WS) is rich in n-6 FA (mainly linoleic acid) and has a protein complex that surrounds 
its lipid content, thus minimizing n-6 FA ruminal biohydrogenation (Lock and Bauman, 2004; Barletta et al., 2016) and increasing the transfer of PUFA into the milk of cows (Gandra et al., 2016).

Besides the effects on health, n-6 FA may directly or indirectly act on physiological processes in the reproductive system by promoting 2-series prostaglandin synthesis and serving as precursor for steroidal hormones (Zachut et al., 2008), altering the function and development of a cumulus-oocyte complex (Wonnacott et al., 2010), modifying gene expression in oocytes (Ponter et al., 2012), or improving embryonic development (Cerri et al., 2009).

According to Ireland (1987), folliculogenesis is a complex process that involves the formation and development of primordial follicles up to the stage of preovulatory follicles. The period required for a primordial follicle to reach a tertiary stage ranges from 80 to $100 \mathrm{~d}$ (preantral phase), and the period required for a tertiary follicle to achieve the preovulatory state (antral phase) is $42 \mathrm{~d}$ (Britt, 1994). Studies have positively correlated FA supplementation with antral follicle development (Ponter et al., 2012), but literature lacks data regarding the duration of FA supplementation in the prepartum period and its influence on follicle and embryo development in the subsequent lactation.

Our hypothesis was that the longer the duration of WS supplementation prepartum, the greater would be the PUFA content in milk fat, and the better would be the oocyte and embryo quality of early-lactating cows. Thus, the objective of this study was to examine different durations of WS supplementation during the prepartum period on milk yield and FA profile, and oocyte and embryo quality of early-lactating dairy cows. Dry matter intake and digestibility, as well as blood metabolites (cholesterol, triglycerides, glucose, urea, NEFA, and BHB) and energy balance (EB), of cows were also assessed.

\section{MATERIALS AND METHODS}

Data from this experiment are discussed in a companion paper. The present article describes the effects of different durations of WS supplementation in the prepartum period on productive and reproductive measures of early-lactating cows, and the other paper examined the influence of WS supplementation on measures of cellular immune function of cows (Gardinal et al., 2018).

\section{Cows, Experimental Design, and Diets}

Forty-four Holstein cows, in late lactation (20.3 $\pm 1.00 \mathrm{~kg} / \mathrm{d}$ of milk yield, $332 \pm 26$ DIM) and $90 \mathrm{~d}$ from the expected day of parturition, were used in a completely randomized design study, balanced for milk production and BCS of cows. Cows were dried off $60 \mathrm{~d}$ before the expected calving date.

At the beginning of the study, 11 cows were assigned to each treatment; however, because of the occurrence of metabolic or infectious disorders not related to experimental treatments ( 3 abortions, 3 displaced abomasum, 3 foot disorders, and 4 dystocia), 13 cows were removed from the study, and only data of healthy cows were evaluated. Cows were distributed to 1 of 4 groups $(\mathrm{G})$ : $\mathbf{G 9 0}(\mathrm{n}=8), \mathbf{G 6 0}(\mathrm{n}=10), \mathbf{G 3 0}(\mathrm{n}=6)$, and G0 (control, $\mathrm{n}=7$ ), supplemented a diet rich in n-6 FA (12\% WS on a DM basis) from 90, 60, 30, and $0 \mathrm{~d}$ relative to the expected calving date, respectively. After parturition, cows were fed a diet containing $12 \%$ of WS on a DM basis until 90 DIM. Diets (Table 1) were formulated according to NRC (2001) recommendations based on the milk production of the previous lactation and supplied twice daily (0800 and $1300 \mathrm{~h}$ ) as a TMR. Diets presented similar NDF, ADF, and $\mathrm{CP}$ in each production stage (Table 1). Dietary ether extract $(\mathbf{E E})$ and $\mathrm{NE}_{\mathrm{L}}$ increased, whereas dietary $\mathrm{NFC}$ content decreased, with WS inclusion. As expected, the amounts and proportion of FA in diets fluctuated according to WS addition in the prepartum period. The calculated values of linoleic acid (\% diet DM) in latelactation diets were 2.4 for G90 and 0.9 for the other treatments. Linoleic acid dietary content (\% DM) in far-off diets was 2.3 for G90 and G60, and linoleic acid was presented at $0.8 \%$ of diet DM for G90 and G0. In close-up diets, G90, G60, and G30 received a diet containing $2.4 \%$ of diet DM of linoleic acid, and G0 received a diet containing $0.8 \%$ of diet DM of linoleic acid. Diets for early-lactating cows had $2.4 \%$ of diet DM of linoleic acid.

At the start of the study, G0 was composed of cows with $2.4 \pm 1.0$ parturitions, $718 \pm 30.6 \mathrm{~kg}$ of $\mathrm{BW}, 3.6$ $\pm 0.20 \mathrm{BCS}$, and milk production of the last lactation of $26.3 \pm 1.3 \mathrm{~kg} / \mathrm{d}$; G30 was composed of cows with $2.7 \pm 1.0$ parturitions, $678 \pm 28.3 \mathrm{~kg}$ of $\mathrm{BW}, 3.5 \pm$ 0.15 BCS, and milk production of the last lactation of $25.9 \pm 1.2 \mathrm{~kg} / \mathrm{d}$; G60 was composed of cows with 2.2 \pm 0.5 parturitions, $671 \pm 26.1 \mathrm{~kg}$ of $\mathrm{BW}, 3.6 \pm 0.15$ BCS, milk production of the last lactation of $26.1 \pm$ $1.5 \mathrm{~kg} / \mathrm{d}$; and G90 was composed of cows with $2.5 \pm$ 0.5 parturitions, $652 \pm 24.9 \mathrm{~kg}$ of $\mathrm{BW}, 3.5 \pm 0.15 \mathrm{BCS}$, and milk production of the last lactation of $26.0 \pm 1.3$ $\mathrm{kg} / \mathrm{d}$ (mean $\pm \mathrm{SD})$.

Throughout the study, cows were housed in individual pens $\left(17.5 \mathrm{~m}^{2}\right.$ of area) containing forced ventilation, sand bedding, individual feed bunks, and free access to water. Amounts of feed offered and orts from each cow were weighed daily and restricted to 5 to $10 \%$ of feed 
intake (on an as-fed basis). Cows were mechanically milked daily at 0630 and $1530 \mathrm{~h}$, with milk production automatically registered (Alpro, DeLaval, Tumba, Sweden).

\section{Sample Collection and Chemical Analyses}

Corn silage was sampled weekly (26 samples), and ingredients of the grain mixture (WS, ground corn, and soybean meal) were collected during the concentrate preparation (6 samples) for chemical analysis. Orts samples (12.5\% of total daily orts) were collected daily from each cow, combined into a composite sample representing each week, and stored at $-20^{\circ} \mathrm{C}$ for posterior chemical analysis. Feed intake was recorded daily as the difference between feed offered and refused. The DM of corn silage was assessed weekly, and adjustments in diets were made when necessary.

Table 1. Ingredients and chemical composition of experimental diets (\% DM unless otherwise stated $)^{1}$

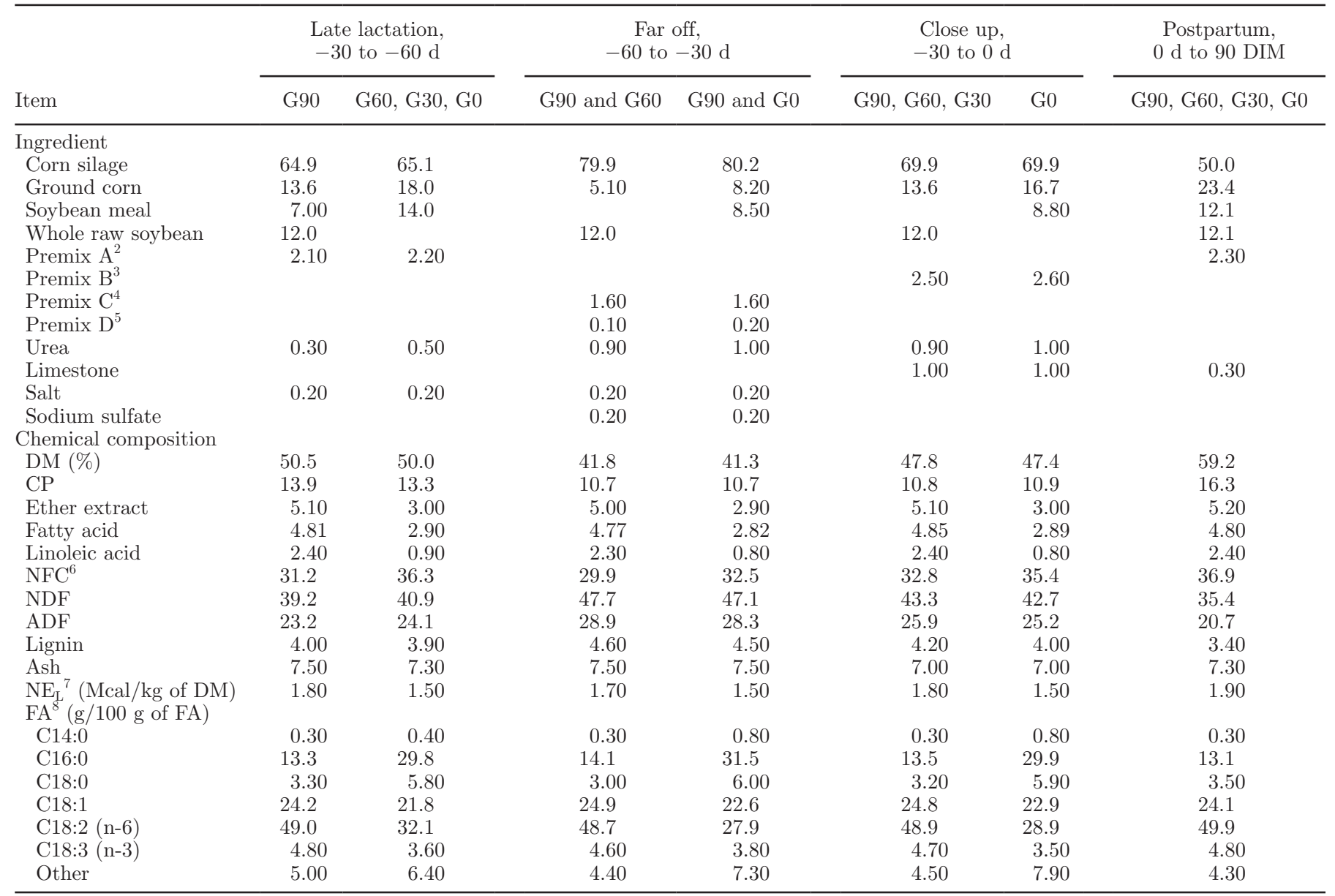

${ }^{1} \mathrm{G} 0=$ cows did not receive whole raw soybeans (WS) throughout the prepartum period; G30, G60, and G90 = groups fed diets containing WS 30,60 , and $90 \mathrm{~d}$ from the expected calving date, respectively.

${ }^{2}$ Contained per kilogram of the product $22.0 \mathrm{~g}$ of Ca, $6.0 \mathrm{~g}$ of $\mathrm{P}, 2.0 \mathrm{~g}$ of $\mathrm{Mg}, 3.5 \mathrm{~g}$ of $\mathrm{K}, 7.0 \mathrm{~g}$ of Na, $2.0 \mathrm{~g}$ of S, $15.0 \mathrm{~g}$ of Co, $700 \mathrm{mg}$ of Cu, 40 $\mathrm{mg}$ of I, $700 \mathrm{mg}$ of Fe, 1,600 mg of Mn, $19 \mathrm{mg}$ of Se, 2,500 mg of Zn, $900 \mathrm{mg}$ (maximum) of Zn, 200,000 IU of vitamin A, 1,200 IU of vitamin E, and 40,000 IU of vitamin D.

${ }^{3}$ Contained per kilogram of the product $12.8 \mathrm{~g}$ of Ca, $3.0 \mathrm{~g}$ of P, $2.0 \mathrm{~g}$ of Cl, $3.1 \mathrm{~g}$ of Na, $9.0 \mathrm{~g}$ of S, $8.0 \mathrm{~g}$ of $\mathrm{Co}, 400 \mathrm{mg}$ of Cu, $60 \mathrm{mg}$ of I, 600 $\mathrm{mg}$ of $\mathrm{Fe}, 800 \mathrm{mg}$ of $\mathrm{Mn}, 12 \mathrm{mg}$ of Se, 1,600 $\mathrm{mg}$ of $\mathrm{Zn}, 900 \mathrm{mg}$ (maximum) of F, 120,000 IU of vitamin A, 40,000 IU of vitamin E, and 50,000 IU of vitamin D.

${ }^{4}$ Contained per kilogram of the product $10.0 \mathrm{~g}$ of $\mathrm{Ca}, 4.2 \mathrm{~g}$ of $\mathrm{P}, 4.5 \mathrm{~g}$ of $\mathrm{Mg}, 2.0 \mathrm{~g}$ of $\mathrm{K}, 12.3 \mathrm{~g}$ of Na, $1.8 \mathrm{~g}$ of S, $14.0 \mathrm{~g}$ of Co, $500 \mathrm{mg}$ of Cu, 28 $\mathrm{mg}$ of I, 1,050 mg of Fe, 1,400 $\mathrm{mg}$ of $\mathrm{Mn}, 18 \mathrm{mg}$ of Se, 2,800 $\mathrm{mg}$ of Zn, $900 \mathrm{mg}$ of F (maximum), 200,000 IU of vitamin A, 1,500 IU of vitamin $\mathrm{E}$, and $50,000 \mathrm{IU}$ of vitamin D.

${ }^{5}$ Contained per kilogram of the product $8.0 \times 10^{6} \mathrm{IU}$ of vitamin A, 50,000 mg of vitamin E, and $2.3 \times 10^{6} \mathrm{IU}$ of vitamin D.

${ }^{6}$ According to the NRC (2001): NFC $=100-(\mathrm{CP}+\mathrm{NDF}+$ ether extract + ash $)$.

${ }^{7}$ Calculated according to Weiss et al. (1992) and NRC (2001) equations, discounting indigestible CP of feed values for level of DMI and using 1 as processing factor.

${ }^{8} \mathrm{FA}=$ fatty acid. 
To analyze FA profile of ingredients, lipid extraction and methylation were performed as described by Sukhija and Palmquist (1988) with minor modifications described below. Extraction was done with 6 $\mathrm{mL}$ of chloroform, and methylations were done with methanolic- $\mathrm{HCl}$ using a concentration of $6.5 \%$ and a volume of $9 \mathrm{~mL}$, with the ratio of extracting solvent to methylation reagent the same in the study by Sukhija and Palmquist (1988).

Methyl-esters of FA were quantified by GC (GC Shimatzu 2010 with automatic injection, Shimadzu Corporation, Kyoto, Japan) equipped with a SP-2560 capillary column $(100 \mathrm{~m} \times 0.25 \mathrm{~mm}$ i.d. with 0.02 $\mu \mathrm{m}$ film thickness; Supelco Sigma-Aldrich Group, Bellefonte, PA). Oven temperature was maintained at $70^{\circ} \mathrm{C}$ for $4 \mathrm{~min}$, increased by $13^{\circ} \mathrm{C} / \mathrm{min}$ until reaching $175^{\circ} \mathrm{C}$, and then held at this temperature for $27 \mathrm{~min}$. Finally, temperature was increased by $4^{\circ} \mathrm{C} / \mathrm{min}$ until reaching $215^{\circ} \mathrm{C}$ and then was kept at $215^{\circ} \mathrm{C}$ for $31 \mathrm{~min}$. Hydrogen was used as the carrier gas, flowing at a rate of $40 \mathrm{~cm}^{3} / \mathrm{s}$. Four standards were used to identify FA: C4-C24 (TM 37, Supelco Sigma-Aldrich Group), C18:1 trans-11 (V038- 1G, Supelco Sigma-Aldrich Group), C18:2 trans-10,cis-12 (UC-61M 100 mg, Nu-Chek Prep Inc., Elysian, MN), and C18:2 cis-9,trans-11 (UC-60M $100 \mathrm{mg}, \mathrm{Nu}$-Chek Prep).

During the prepartum period, fecal samples were collected directly from the rectum of cows twice daily (0800 and $1300 \mathrm{~h}$ ) on d 56 and 21 before the expected calving date, and postpartum fecal samples were collected after milking (morning and afternoon) on d 21, 56 , and 84 to determine nutrients excreted in feces and daily fecal excretion.

Samples of feed, orts, and feces were dried at $55^{\circ} \mathrm{C}$ in a forced-air oven for $72 \mathrm{~h}$ and ground in a knives mill to pass through a 1-mm screen (Wiley mill, A. H. Thomas, Philadelphia, PA). Samples were then analyzed for gross energy using a bomb calorimeter (IKA Works GmbH \& Co., Staufen, Germany), DM (method 950.15), ash (method 942.05), EE (method 920.39), CP $(\mathrm{N} \times 6.25$; method 984.13), and lignin (method 973.18) according to the methods described by AOAC International (2000). Neutral detergent fiber was analyzed using $\alpha$-amylase without addition of sodium sulfite to the detergent (TE-149 fiber analyzer; Tecnal Equipments for Laboratory Inc., Piracicaba, Brazil). Acid detergent fiber was determined as described by Van Soest et al. (1991). Nonfiber carbohydrates concentrations were estimated as $\mathrm{NFC}=100-(\% \mathrm{CP}+\% \mathrm{EE}+\%$ ash $+\% \mathrm{NDF})$.

Indigestible ADF (iADF) was used as an internal marker to estimate daily fecal DM excretion of cows (Nocek, 1988). Samples of feed, orts, and feces were dried at $55^{\circ} \mathrm{C}$ in a forced-air oven for $72 \mathrm{~h}$ and ground in a knives mill to pass through a 2 -mm screen (Wiley Mill, A. H. Thomas). Samples were placed in $5 \times 5$ $\mathrm{cm}$ nonwoven textile bags $\left(20 \mathrm{mg}\right.$ of $\mathrm{DM} / \mathrm{cm}^{2}$ of surface) as described by Nocek (1988), and then bags were incubated for $288 \mathrm{~h}$ in the rumen of 2 fistulated dry cows adapted to the lactation diet of the present study. After $288 \mathrm{~h}$, bags were removed from the rumen and washed in running tap water, dried at $55^{\circ} \mathrm{C}$ in a forcedair oven for $72 \mathrm{~h}$, and submitted to treatment with acid detergent (Van Soest et al., 1991) in a fiber analyzer (TE-149 fiber analyzer, Tecnal Equipments for Laboratory Inc.) to determine iADF concentrations. Apparent total-tract digestibility values were obtained as follows:

$$
\begin{gathered}
\text { DM digestibility }= \\
100-[100 \times(\% \text { iADF intake } / \% \text { iADF in feces })] \\
\text { Nutrient digestibility }= \\
100-[100 \times(\% \text { iADF intake } / \% \text { iADF in feces }) \\
\times(\% \text { nutrient in feces } / \% \text { nutrient in diet })] .
\end{gathered}
$$

\section{Milk Yield and Composition}

Cows were mechanically milked daily at 0600 and $1600 \mathrm{~h}$, and production was measured by an automatic milk meter (Alpro, DeLaval). Milk production was corrected to $3.5 \%$ of fat $(\mathrm{FCM})$, in which $\mathrm{FCM}=(0.432+$ $0.1625 \times$ milk fat concentration $) \times$ milk yield $(\mathrm{kg} / \mathrm{d})$. Milk yield was also corrected to energy content as follows: $\mathrm{ECM}(\mathrm{kg} / \mathrm{d})=0.327 \times$ milk yield $+12.86 \times$ fat yield $+7.65 \times$ protein yield (Dairy Records Management Systems, 2013). Milk samples were automatically collected (Alpro, DeLaval) according to the milk yield of each cow every week. Samples from each milking shift were combined before milk components analysis. Milk samples were analyzed for fat, protein, and lactose by infrared methodology (Lactoscan; Entelbra, Sao Paulo, Brazil). After the milk composition assay, samples were stored at $-20^{\circ} \mathrm{C}$ for later analyses of FA profile. Milk lipid extraction was performed according to Feng et al. (2004) and methylated according to Kramer et al. (1997). Fatty acid profile in milk was determined by GC, as previously described.

\section{$B C S$ and $B W$}

Body weights were measured weekly before the morning feeding and after milking using a livestock scale for large animals (Brete ME 2.80; Coimma, Dracena, Brazil). Body condition score was measured using a 5 -point system $(1=$ emaciated to $5=$ obese $)$. 


\section{EB and Absorbed Nitrogen}

Energy values were calculated as follows: digestible energy intake $=$ gross energy intake $\times$ gross energy digestibility; $\mathrm{NE}_{\mathrm{L}}$ intake was calculated from digestible energy through metabolizable energy according to the NRC (2001). Milk $\mathrm{NE}_{\mathrm{L}}(\mathrm{Mcal} / \mathrm{d})=$ milk yield $(\mathrm{kg}) \times$ $[0.0929 \times($ fat \% $)+0.0563 \times($ true protein \% $)+0.0395$ $\times$ (lactose \%)] (NRC, 2001); $\mathrm{NE}_{\mathrm{L}} \mathrm{BW}$ gain was calculated according to the $\mathrm{NRC}(2001) ; \mathrm{NE}_{\mathrm{L}}$ requirements for maintenance $=0.080 \mathrm{Mcal} / \mathrm{kg}$ of $\mathrm{BW}^{0.75}(\mathrm{NRC}$, 2001); and $\mathrm{NE}_{\mathrm{L}}$ available for maintenance $=\mathrm{NE}_{\mathrm{L}}$ intake $-\mathrm{NE}_{\mathrm{L}}$ milk $-\mathrm{NE}_{\mathrm{L}} \mathrm{BW}$ gain. Energy balance was calculated as follows: $\mathrm{EB}(\mathrm{Mcal} / \mathrm{d})=\mathrm{NE}_{\mathrm{L}}$ intake (milk $\mathrm{NE}_{\mathrm{L}}+\mathrm{NE} \mathrm{BW}$ gain $+\mathrm{NE}$ maintenance) according to the NRC (2001). Efficiency of energy utilization was calculated as follows: efficiency $=\mathrm{NE}_{\mathrm{L}}$ /digestible energy intake. Absorbed N (g/d) was estimated as follows: $\mathrm{N}$ intake $-\mathrm{N}$ excreted in feces.

\section{Blood Metabolites}

Blood samples were collected from coccygeal vessels in sterile vacutainers without clot activator before the morning feeding $(0700 \mathrm{~h})$ on days $-49,-35,-21,-14$, and -7 relative to the expected calving date, at the partum day, and on d 7, 14, 21, 35, and 70 of lactation. After the clot formation, blood samples were centrifuged at 2,000 $\times g$ for $15 \mathrm{~min}$ at $4^{\circ} \mathrm{C}$, and serum was stored at $-20^{\circ} \mathrm{C}$. Blood was assessed for cholesterol, triglycerides, glucose, urea, NEFA, and BHB concentrations. Analyses of cholesterol, triglycerides, and glucose were performed by colorimetric method using commercial kits (Bioclin, Belo Horizonte, Brazil), and readings were performed in a semi-automatic spectrophotometer (SBA 200, CELM, Sao Caetano do Sul, Brazil). The NEFA and BHB assays were performed using commercial kits (Randox FA115 and Ranbut RB100, Crumlin, UK) by an enzymatic colorimetric endpoint method, and readings were performed in a microplate reader (Asys Brand, Model UV-Plus Expert, Biochrom, Cambridge, UK).

\section{In Vitro Fertilization and Embryo Quality}

Ovum pick-ups were performed on $\mathrm{d} 21 \pm 3,42 \pm$ $7,63 \pm 7$, and $84 \pm 7$ of lactation, according to the methods described by Pontes et al. (2011), and embryos were produced according to Pontes et al. (2009), in which all procedures were carried out by In Vitro Brasil Ltda. (Mogi Mirim, Brazil). Oocytes were classified as follows: grade 1: spherical, symmetrical, and intact oocytes of uniform size, color, and texture, surrounded by $\geq 3$ compact layers of cumulus cells; grade
2: incomplete cumulus layer, oocyte partially denuded; grade 3: cumulus expanded, oocyte denuded, partially degenerated cumulus; and grade 4: totally degenerated cumulus and oocyte (de Loos et al., 1989). Atretic and degenerated oocytes were discarded. The remaining oocytes were washed 3 times in TCM-199 HEPES (Gibco Life Technologies, Grand Island, NY) containing gentamycin sulfate, and then they were washed once in bicarbonate TCM-199 (Gibco Life Technologies) containing fetal calf serum, FSH, estradiol, pyruvate, and sulfate gentamycin. Cumulus-oocyte complexes were separated after 24-h culture in mineral oil. Frozen semen of a single sire with known fertility was used in in vitro fertilization. Sperm concentration was adjusted to $25 \times$ $10^{6}$ live sperm $/ \mathrm{mL}$, and each fertilization drop received $4 \mu \mathrm{L}$ of sperm. Embryos were classified according to Wright (1998). The drugs and medium culture used in the current study are described by Pontes et al. (2011).

\section{Statistical Analyses}

The data were subjected to SAS (Version 9.1.3, 2014, SAS Institute Inc., Cary, NC), verifying the normality of residuals and homogeneity of variances by PROC UNIVARIATE. Data were analyzed by PROC MIXED as repeated measures according to the model below:

$$
Y_{i j k}=\mu+D_{i}+T_{j}+D_{i} \times T_{j}+a_{k}+e_{i j k},
$$

where $Y_{i j k}=$ dependent variable; $\mu=$ overall mean; $D_{i}=$ fixed effect of duration of WS supplementation; $T_{j}=$ fixed effect of time; $D_{i} \times T_{j}=$ fixed effect of duration of WS supplementation by time interaction; $a_{k}=$ random effect of animal; and $e_{i j k}=$ residual. The degrees of freedom were calculated according to the Satterthwaite's method (ddfm $=$ satterth $)$. Covariance structure was selected based on the Akaike's information criterion. For covariate adjustment, first we used DMI and milk yield of previous lactation, but they were not significant in the statistical model. Then, covariate adjustment was performed using the initial BW and BCS of cows. Differences among experimental groups were tested through polynomial simple regression using linear and quadratic contrasts. Significance was set at $P<0.05$.

\section{RESULTS}

\section{Diet and Ingredient Composition}

Diets had similar NDF, ADF, and CP for each productive stage of cows (Table 1). Dietary EE and $\mathrm{NE}_{\mathrm{L}}$ increased, whereas dietary NFC content decreased. As expected, the amounts of $\mathrm{EE}$ and proportion of FA in 
diets fluctuated according to WS addition in the prepartum period. Diet EE content ranged from $2.99 \%$ up to $5.11 \%$ of DM, and dietary concentration of C18:2 FA ranged from 27.9 up to $49.9 \mathrm{~g} / 100 \mathrm{~g}$ of FA.

\section{DMI, Apparent Total-Tract Digestibility, and Absorbed Nitrogen}

Different durations of WS supplementation during the prepartum period did not affect DMI, apparent total-tract digestibility, and absorbed nitrogen in the pre- and postpartum periods (Table 2). A time effect was noticed for almost all parameters, excepted for DM and EE apparent total-tract digestibility in the prepartum period $(P \geq 0.205)$. No interaction effect $(P \geq$ 0.067 ) of duration of WS supplementation by time was observed on DMI, digestibility, and retained nitrogen.

\section{Milk Yield and Composition, EB, Efficiency of Nutrient Utilization, BCS, and BW}

Milk yield and composition as well as the EB of cows were not affected $(P \geq 0.260)$ by the different lengths of WS supplementation (Table 3 ). The EB became negative approximately at $1 \mathrm{wk}$ before the partum, and $\mathrm{EB}$ first became positive in G60 (between 21 and 28 DIM) and then became positive in the other experimental groups (between 28 and 35 DIM; Figure 1). Efficiency of nitrogen, energy utilization, BCS, and BW were similar among experimental groups $(P>0.498)$. Time effect was noticed $(P \leq 0.012)$ for almost all parameters, excepted for $3.5 \%$ FCM and ECM yields $(P \geq$ $0.138)$.

\section{Milk FA Profile}

Different durations of WS supplementation during the prepartum period linearly decreased $(P \leq 0.048)$ concentrations of cis-9 C16:1, cis-9 C18:1, unsaturated C18, total MUFA, and total UFA in milk fat, and linearly increased total SFA and SFA:UFA in milk fat. Yet, different durations of WS supplementation during the prepartum period had a positive quadratic effect $(P \leq 0.047)$ on milk fat concentrations of $c i s-9$, cis-12 C18:2, cis-9,trans-11 CLA, and total PUFA, wherein the content of these FA were increased in G30 (Table 4). A time effect was noticed for almost all parameters, and a group effect was observed on concentrations of cis-9 C16:1, cis-9,trans-11 CLA, cis-11 C20:1, unsaturated $\mathrm{C} 18$, total SFA, and total others $\mathrm{FA}$, in which longer periods of WS supplementation resulted in lower UFA and higher SFA in milk.

\section{Blood Metabolites}

The length of WS supplementation before calving linearly increased $(P=0.009)$ blood cholesterol concentration of cows during the prepartum period (Table 5; Figure 2). Whole raw soybean supplementation during the prepartum period did not affect $(P \geq 0.120)$ blood triglycerides, glucose, urea, NEFA, and BHB concentrations in the pre- and postpartum periods. No group by time interaction effects were detected $(P \geq 0.057)$ on blood metabolites. The highest blood NEFA concentration was observed at the first week after parturition, and then it gradually decreased according to DIM, regardless of the experimental group (data not shown).

\section{Oocyte and Embryo Production and Quality}

Dietary supplementation of WS during the prepartum period had a positive quadratic effect $(P=0.039)$ on the average number of grade 2 oocytes, wherein all groups that received WS during the prepartum period exhibited a higher number of grade 2 oocytes in relation to G0, but cows in G60 showed the highest value (Table 6; Figure 3). The length of WS supplementation did not affect $(P \geq 0.281)$ embryo quality of cows.

\section{DISCUSSION}

The length of WS supplementation during the prepartum period had no effects on DMI and nutrient digestibility in the pre- and postpartum periods of cows. Although WS have a relatively high content of PUFA, which have been associated with impairments in rumen fiber degradability and fermentation (Oldick and Firkins, 2000), WS possess a protein complex that surrounds oil content in the seed, protecting it against ruminal biohydrogenation and minimizing PUFA negative effects on fiber digestibility and feed intake of animals (Venturelli et al., 2015; Barletta et al., 2016). Previous studies with transition and early-lactating cows have reported no differences in DMI when supplying oilseeds (WS and whole flaxseed) to transition cows (Gandra et al., 2016).

The length of WS supplementation did not alter milk yield and composition, being that these outcomes were partially related to the lack of WS effects on DMI and $\mathrm{NE}_{\mathrm{L}}$ intake. Differences in ruminal fermentation account for most of the changes in milk production and composition, but WS supplementation seems to not affect VFA concentration in the rumen of dry and lactating cows (Almeida et al., 2016; Bettero et al., 2017). Agreeing with the current study, Badiei et al. 
WHOLE RAW SOYBEANS TO TRANSITION COWS

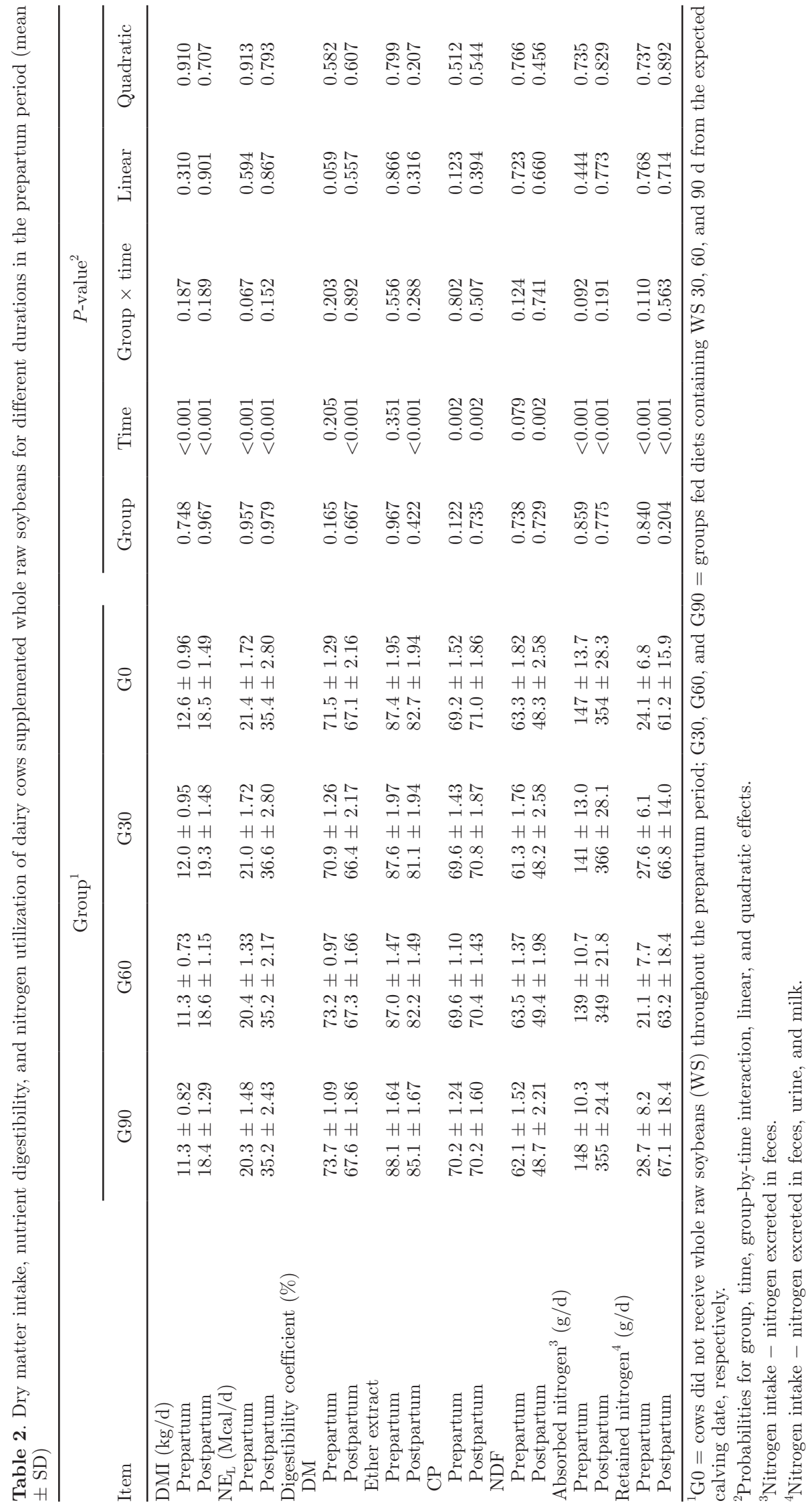


GARDINAL ET AL.

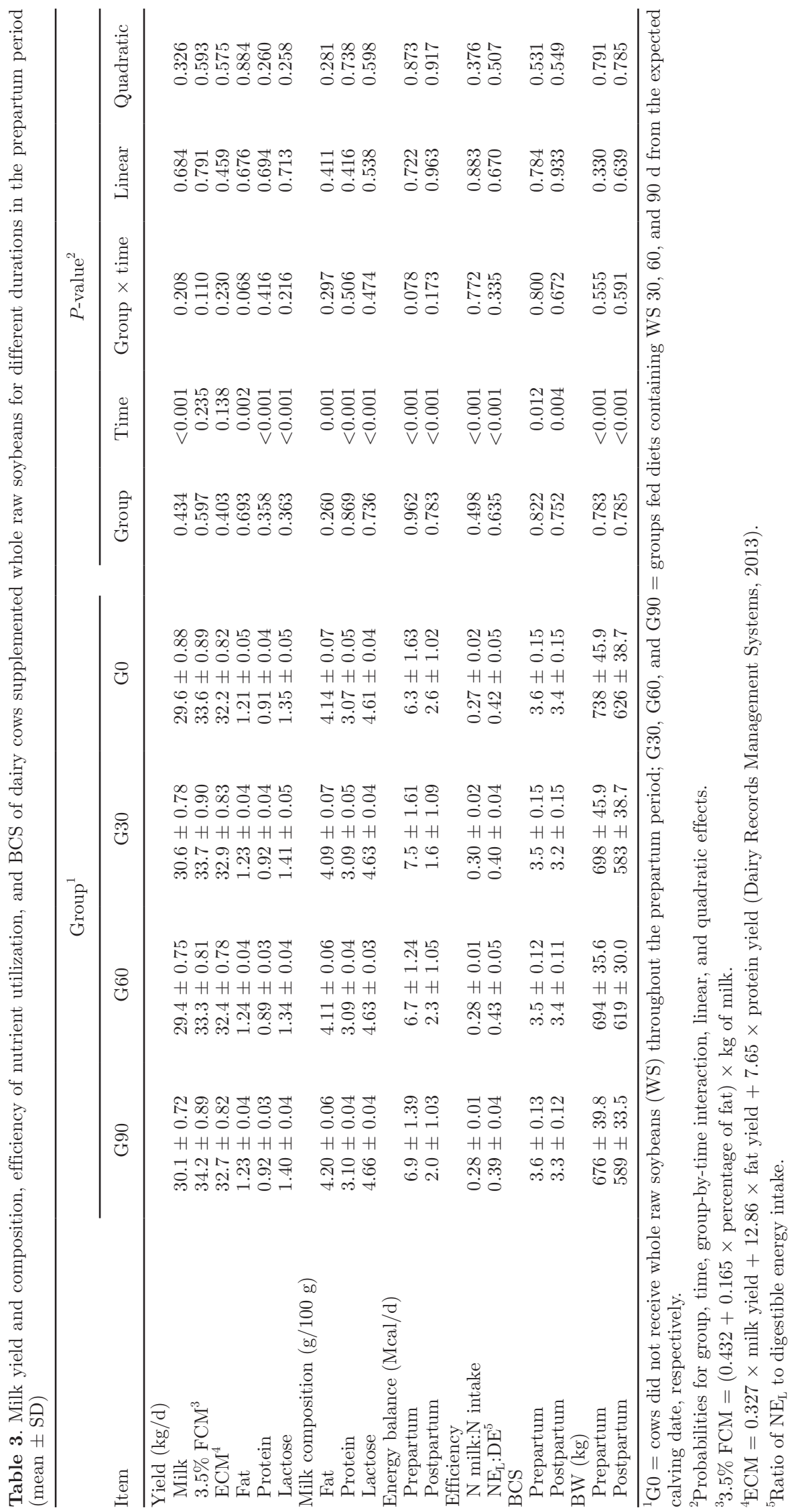




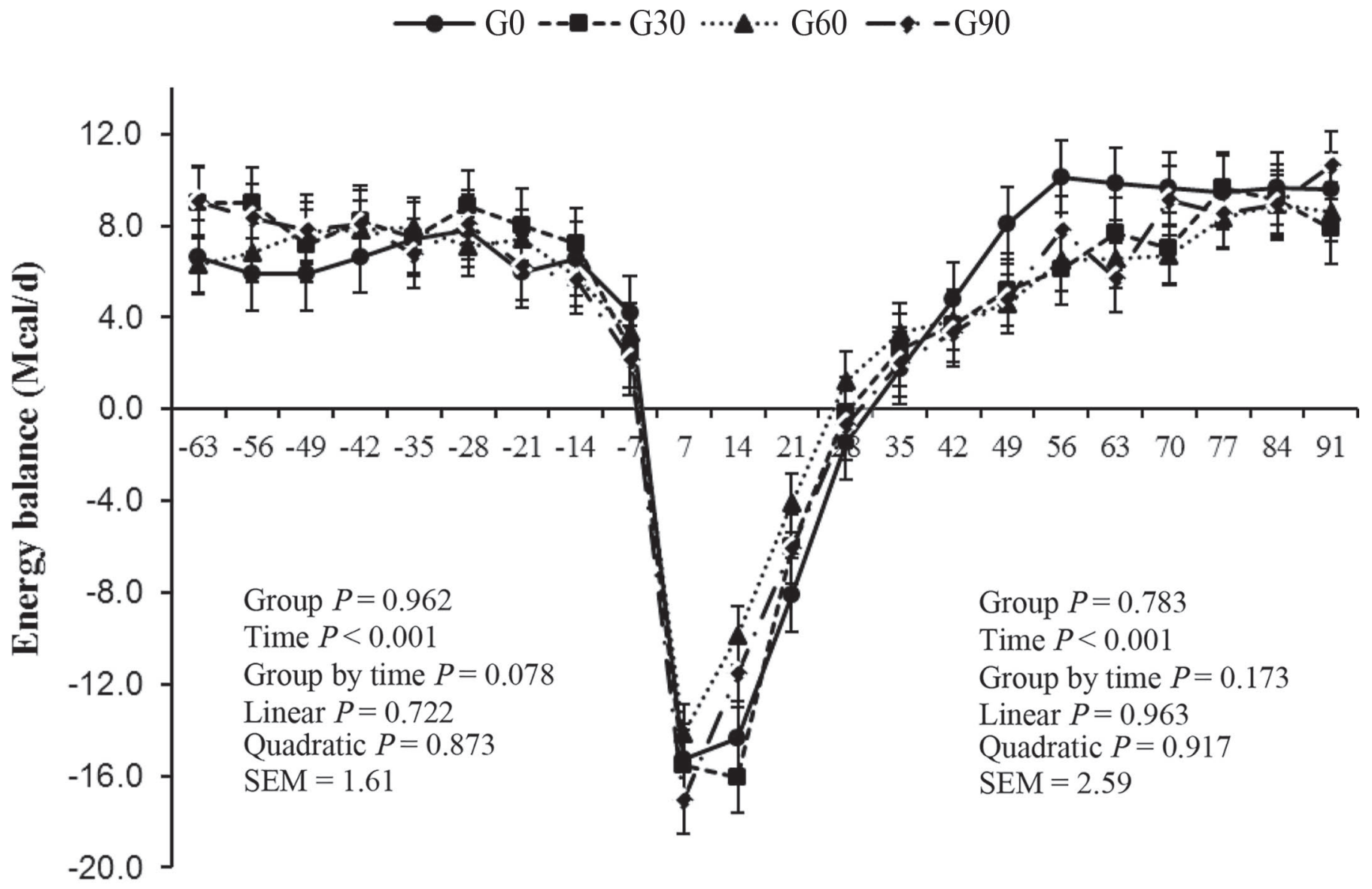

Days relative to parturition

Figure 1. Effects of different durations of whole raw soybean (WS) supplementation in the prepartum period on energy balance of transition cows. G0 = cows did not receive WS throughout the prepartum period; G30, G60, and G90 = groups that received a diet containing WS from $-30,-60$, and $-90 \mathrm{~d}$ relative to the expected calving date, respectively. Error bars represent SE.

(2014) evaluated different lengths $(-8,-5$, and $-3 \mathrm{wk}$ relative to partum) of flaxseed supplementation and reported no changes in milk yield and composition of cows. Further, Gandra et al. (2016) also provided a diet with $12 \%$ WS during the prepartum period ( -35 $\mathrm{d}$ relative to partum) and did not report differences in milk yield and composition during the early lactation of cows.

In general, the longer the duration of WS supplementation in the prepartum period, the greater was the total SFA and the lower were the total UFA and MUFA contents in milk. Changes in milk FA, in this situation, are likely a consequence of increased biohydrogenation efficiency of rumen microbiota. Microbiota adaptation and biohydrogenation efficiency are positively correlated with the length of PUFA supplementation (Palmquist and Mattos, 2006; Hobson and Stewart, 2012). In addition, the BCS and EB of cows were not affected by the duration of WS supplementa- tion. The degree of mobilization of body reserves may influence milk FA profile in dairy cows (Nogalski et al., 2012); therefore, the most reasonable explanation for the changes in milk FA profile of cows, in the current experiment, is related to increased biohydrogenation efficiency of ruminal bacteria. It is highlighted that WS supplementation starting at $-30 \mathrm{~d}$ relative to parturition showed the highest values of cis-9,trans-11 CLA and total PUFA content in milk of cows, with it being reasonable to suppose an increase of CLA and PUFA content also in blood.

Blood glucose, NEFA, nor BHB concentrations in the pre- and postpartum periods were affected by WS supplementation. Generally, blood glucose concentration of cows is not affected by WS supplementation either when provided during the dry period (Bettero et al., 2017) or during the lactation (Castañeda-Gutiérrez et al., 2007; Almeida et al., 2016). Differences in blood glucose concentration among treatments are not ex- 


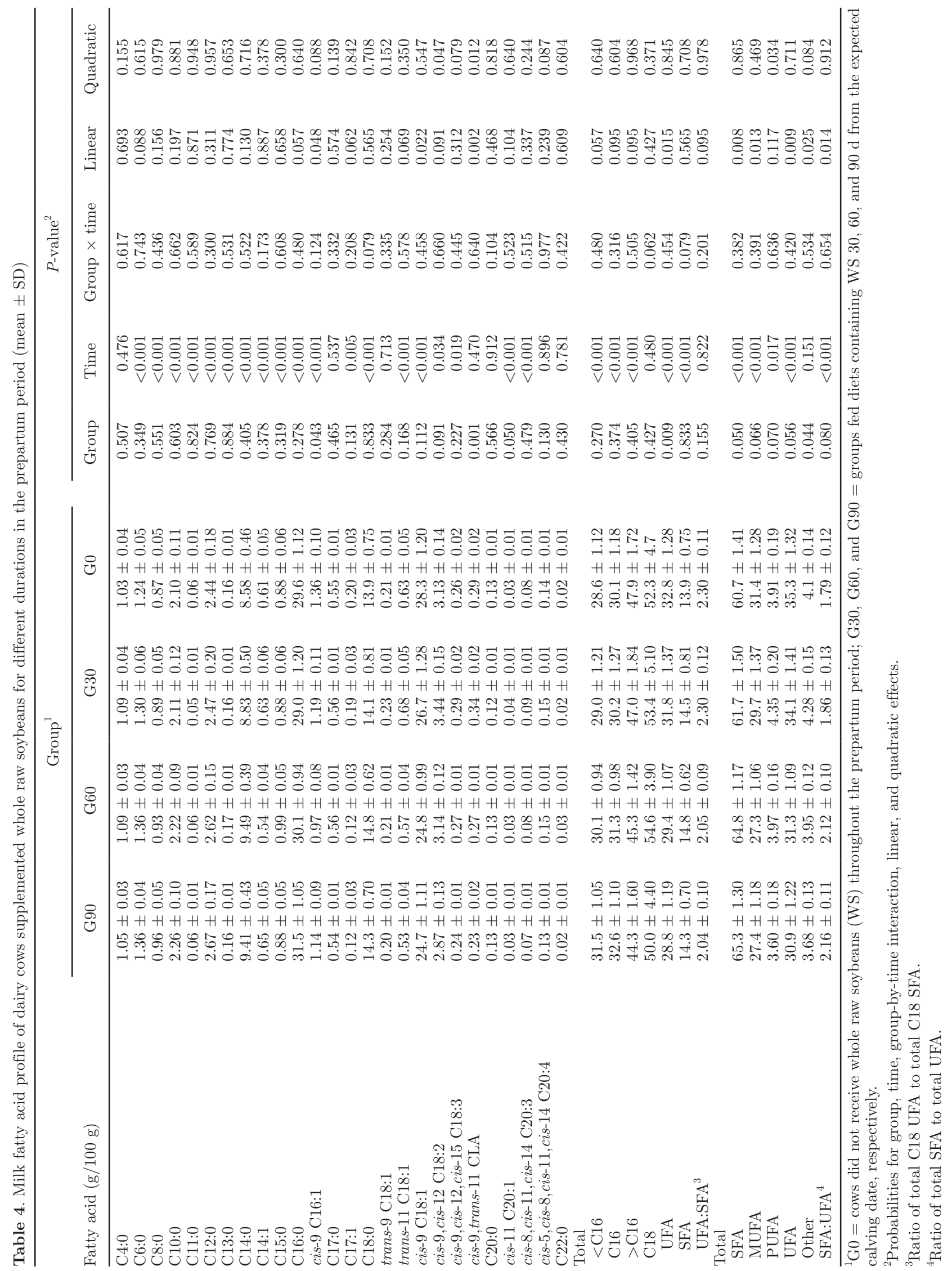



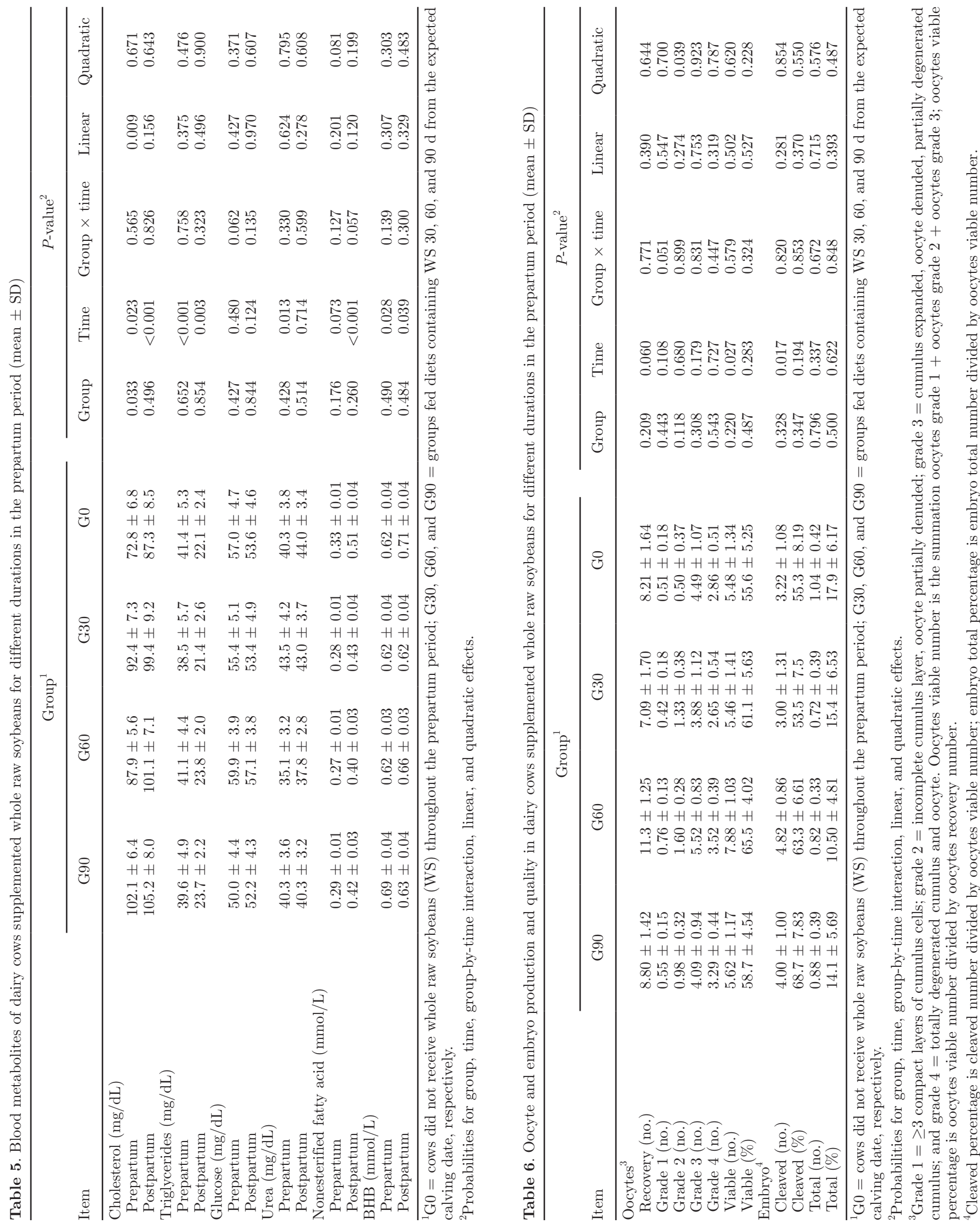
pected because homeostatic mechanisms (cell uptake by passive and facilitated transports) maintain blood glucose concentration within a narrow range (Widdas, 1988). Although, a peak of glucose in blood often occurs at parturition because of the release of glucocorticoids immediately before the partum (Leury et al., 2003). Blood NEFA and BHB concentrations are markers of NEB in transition cows (McArt et al., 2012). During early lactation, cows are unable to achieve energy requirements for relatively high milk production from feed intake alone. Therefore, fresh cows mobilize body reserves (especially from adipose tissue) in an attempt to meet nutritional requirements. Adipose tissue mobilization leads to an increase in blood NEFA concentration that can be metabolized in hepatocytes into ketones (BHB), wherein both NEFA and BHB can be used as fuels to the mammary gland (Drackley, 1999). In the current experiment, WS supplementation had no effect on BW, BCS, EB, and milk and fat production of cows; thus, the lack of effects of WS on NEB markers is expected.

The duration of WS supplementation increased blood cholesterol concentration in the prepartum period. Feeding fat sources for ruminants increases highdensity lipoprotein cholesterol in blood (Storry et al., 1980) and augments lipoprotein cholesterol export in the intestine (Noble, 1981). Indeed, WS provision to dairy cows often increases blood cholesterol concentration (Almeida et al., 2016; Naves et al., 2016; Gandra et al., 2017). In addition, Staples et al. (1998) observed an increase in cholesterol concentration in follicle fluid and blood after cows received supplemental fat. All cows were fed WS after parturition and, consequently, had similar values of blood cholesterol in this period.

Linoleic acid has shown positive effects, regardless of the amounts of calories consumed or changes in energy
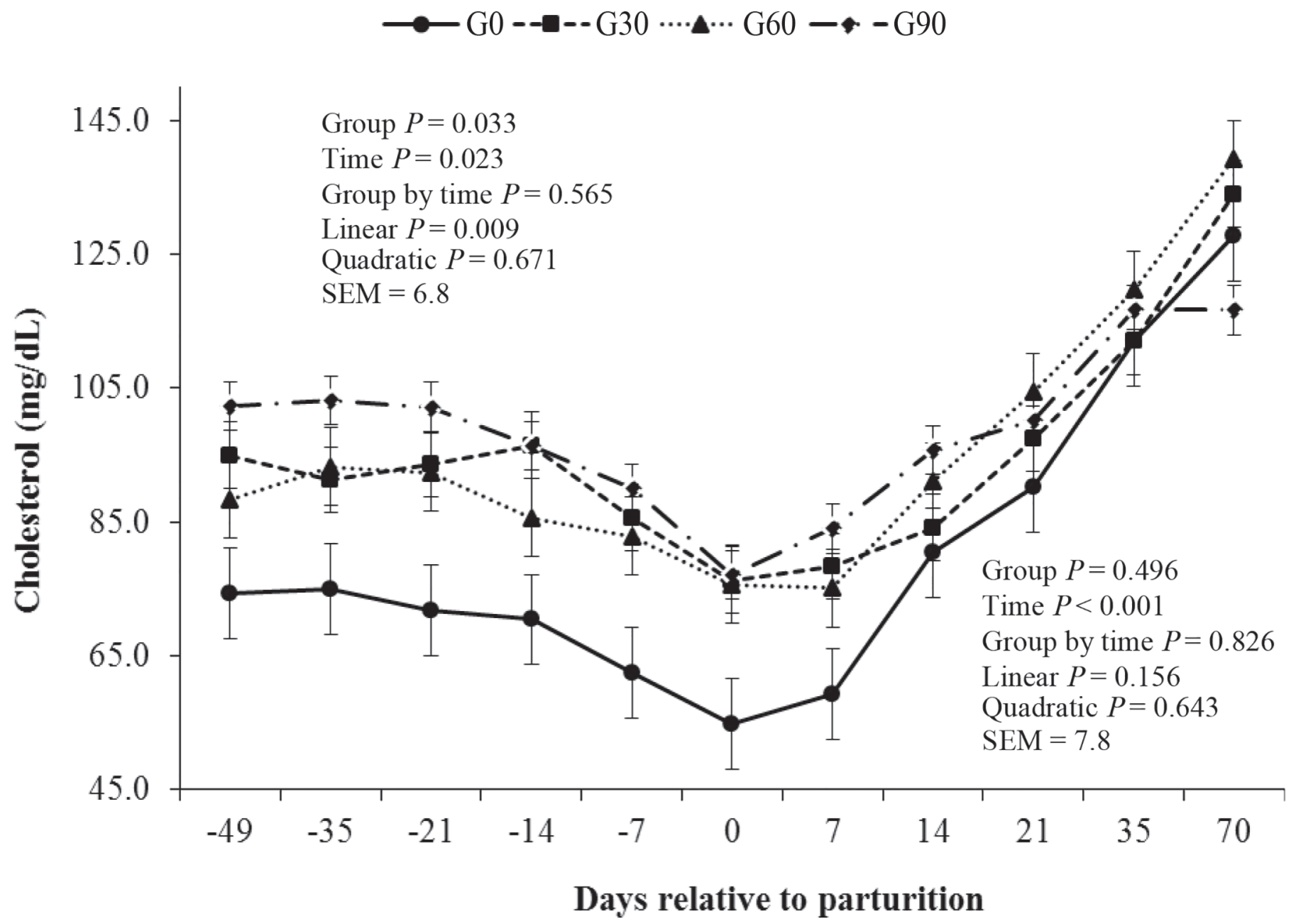

Figure 2. Effects of different durations of whole raw soybean (WS) supplementation in the prepartum period on blood cholesterol concentration of transition cows. G0 = cows did not receive WS throughout the prepartum period; G30, G60, and G90 = groups that received a diet containing WS from $-30,-60$, and $-90 \mathrm{~d}$ relative to the expected calving date, respectively. Error bars represent SE. 
status, on fertility of dairy cows (Staples et al., 1998; Santos et al., 2008). In the current experiment, WS supplementation in the prepartum period increased the amounts of grade 2 oocytes in cows, notably when feeding WS to cows was started at $-60 \mathrm{~d}$ relative to the expected calving date. Polyunsaturated FA, such as linoleic acid, can affect oocyte quality by integrating the oocyte phospholipid membrane, altering its fluidity and processes mediated by the membrane (Grammatikos et al., 1994). Although morphological quality of an oocyte (compactness and number of layers of cumulus cells) has been associated with better rates of in vitro maturation, fertilization, and development to the morula and blastocyst stages (Khurana and Niemann, 2000), the current experiment did not find improvements in embryo cleavage. Few studies evaluated soybean supplementation on oocyte and embryo quality of dairy cows, and outcomes have been variable. Gandra et al. (2017) reported that WS supplementation for transition cows had no effect on oocyte quality and found a decrease in the amounts of viable embryos. Ponter et al. (2012) supplemented Holstein heifers with extruded linseed or soybeans and did not observe differences in oocyte (number, quality, fertilization, and cleavage) and embryo (number and quality) traits.
In the current study, animals showed a greater number of viable oocytes as the lactation progressed, regardless of the experimental group. This fact is probably related to animal energy state; animals were in NEB during the first 3 wk after parturition and, consequently, had high amounts of NEFA in the blood stream. High blood NEFA concentration may impair follicle development and decrease its viability (Walsh et al., 2011).

\section{CONCLUSIONS}

Supplementing cows with WS from -30 d relative to parturition increased PUFA (especially of linoleic acid) content in milk of cows. The PUFA transfer to the milk decreased when supplementing WS for longer periods than $-60 \mathrm{~d}$ relative to partum, suggesting rumen microbiota adaptation to fat supplementation. Further, longer periods of WS supplementation did not affect blood levels of cholesterol, NEFA, and BHB in the postpartum period. The current experiment, did not find effects of WS supplementation on embryo quality of dairy cows. Finally, WS can be fed without negative effects on performance parameters of transition and early-lactating cows (DMI, digestibility, EB, and milk production).

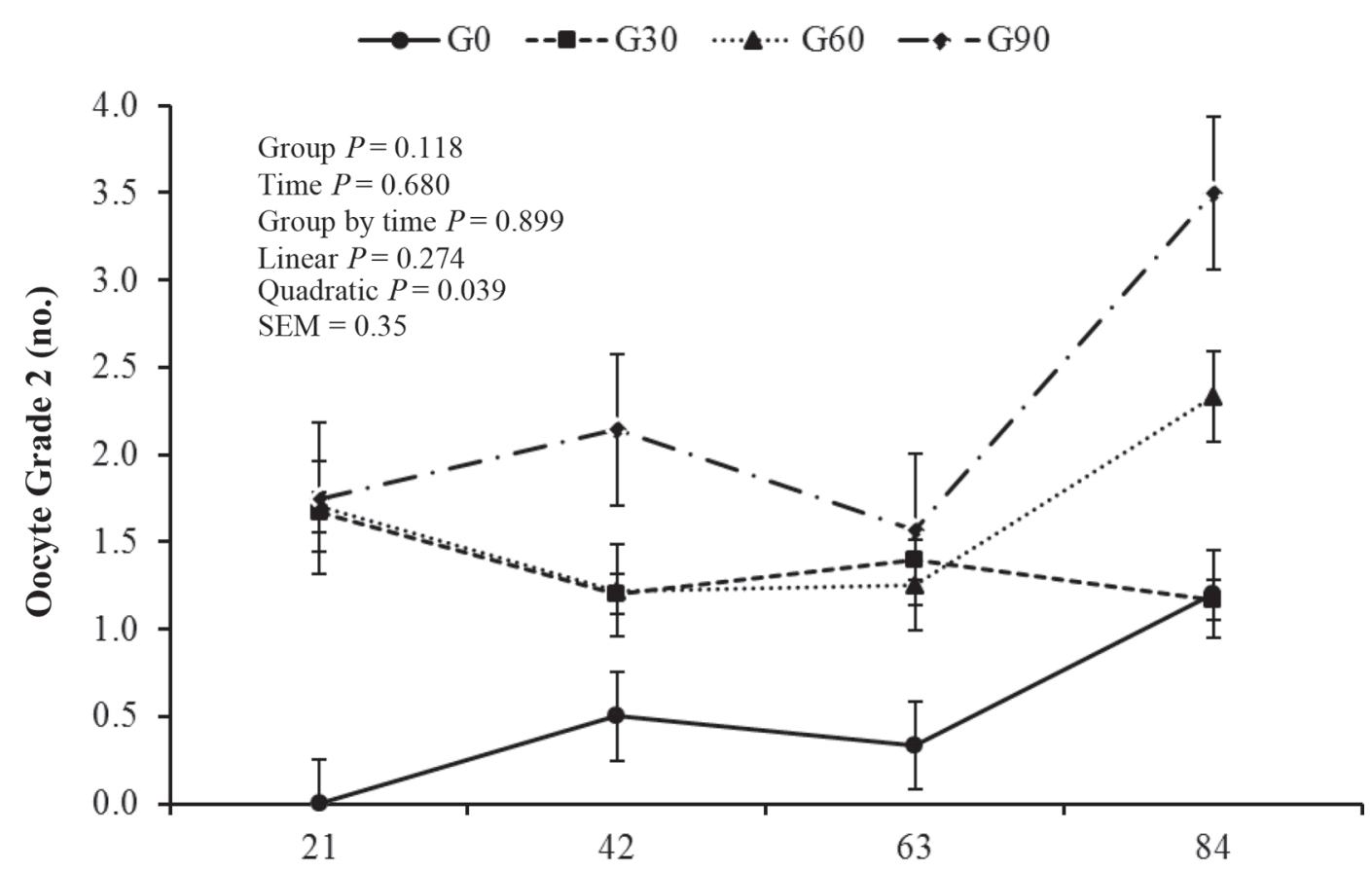

\section{Days relative to parturition}

Figure 3. Effects of different durations of whole raw soybean (WS) supplementation in the prepartum period on number of viable oocytes of dairy cows. G0 = cows did not receive WS throughout the prepartum period; G30, G60, and G90 = groups that received a diet containing WS from $-30,-60$, and $-90 \mathrm{~d}$ relative to the expected calving date, respectively. Error bars represent SE. 


\section{ACKNOWLEDGMENTS}

The authors acknowledge the University of Sao Paulo and the Dairy Cattle Research Laboratory for providing the infrastructure and staff necessary for this study. In addition, the authors express appreciation to Sao Paulo Research Foundation for financial support (grant \#2012/02360-1). Finally, we are grateful to In Vitro Brasil s/a for supporting the embryo production procedures.

\section{REFERENCES}

Almeida, G. F., T. A. Del Valle, P. G. Paiva, E. F. Jesus, R. V. Barletta, J. R. Gandra, V. P. Bettero, C. S. Takiya, and F. P. Rennó. 2016. Effects of whole raw soybean or whole cottonseed on milk yield and composition, digestibility, ruminal fermentation and blood metabolites of lactating dairy cows. Anim. Prod. Sci. $57: 122-128$.

AOAC International. 2000. Official Methods of Analysis. 17th ed. AOAC Int., Arlington, VA.

Badiei, A., A. Aliverdilou, H. Amanlou, M. Beheshti, E. Dirandeh, R. Masoumi, and F. Moosakhani. 2014. Postpartum responses of dairy cows supplemented with n-3 fatty acids for different durations during the peripartal period. J. Dairy Sci. 97:6391-6399.

Barletta, R. F., J. R. Gandra, V. P. Bettero, C. E. Araújo, T. A. Del Valle, G. F. Almeida, E. F. Jesus, R. D. Mingoti, B. C. Benevento, J. E. Freitas Júnior, and F. P. Rennó. 2016. Ruminal biohydrogenation and abomasal flow of fatty acids in lactating cows: Oilseed provides ruminal protection for fatty acids. Anim. Feed Sci. Technol. 219:111-121.

Bettero, V. P., T. A. Del Valle, R. V. Barletta, C. E. Araújo, E. Ferreira de Jesus, G. F. Almeida, C. S. Takiya, F. Zanferari, P. G. Paiva, J. E. Freitas Júnior, and F. P. Rennó. 2017. Use of protected fat sources to reduce fatty acid biohydrogenation and improve abomasal flow in dry dairy cows. Anim. Feed Sci. Technol. 224:30-38.

Britt, J. H. 1994. Follicular development and fertility: Potential impacts of negative energy balance. Pages 103-112 in Proc., Natl. Reprod. Symp. Am. Assoc. Bovine Pract., Auburn, AL.

Castañeda-Gutiérrez, E., M. J. de Veth, L. A. Lock, D. A. Dwyer, K. D. Murphy, and D. E. Bauman. 2007. Effect of supplementation with calcium salts of fish oil on n-3 fatty acids in milk fat. J. Dairy Sci. 90:4149-4156.

Cerri, R. L. A., S. O. Juchem, R. C. Chebel, H. M. Rutigliano, R. G. S. Bruno, K. N. Galvão, W. W. Thatcher, and J. E. P. Santos. 2009. Effect of fat source differing in fatty acid profile on metabolic parameters, fertilization, and embryo quality in high-producing dairy cows. J. Dairy Sci. 92:1520-1531.

Contreras, G. A., and L. M. Sordillo. 2011. Lipid mobilization and inflammatory responses during the transition period of dairy cows. Comp. Immunol. Microbiol. Infect. Dis. 34:281-289.

Dairy Records Management Systems. 2013. DHI Glossary. Accessed May 17, 2014. http://www.drms.org/.

de Loos, F., C. Van Vliet, P. Van Maurik, and T. A. Kruip. 1989. Morphology of immature bovine oocytes. Gamete Res. 24:197-204.

Drackley, J. K. 1999. Biology of dairy cows during the transition period: The final frontier? J. Dairy Sci. 82:2259-2273.

Feng, S., A. L. Lock, and P. C. Garnsworthy. 2004. A rapid method for determining fatty acid composition of milk. J. Dairy Sci. $87: 3785-3788$.

Gandra, J. R., R. D. Mingoti, R. V. Barletta, C. S. Takiya, L. C. Verdurico, J. E. Freitas Jr., P. G. Paiva, E. F. Jesus, G. D. Calomeni, and F. P. Rennó. 2016. Effects of flaxseed, raw soybeans and calcium salts of fatty acids on apparent total tract digestibility, energy balance and milk fatty acid profile of transition cows. Animal 10:1303-1310.
Gandra, J. R., L. C. Verdurico, R. D. Mingoti, C. S. Takiya, R. Gardinal, T. H. A. Vendramini, R. V. Barletta, J. A. Visintin, and F. P. Rennó. 2017. Whole flaxseed, raw soybeans and calcium salts of fatty acids supplementation for transition cows: Follicle development and embryo quality. Ital. J. Anim. Sci. https://doi.org/10 $.1080 / 1828051$ X.2017.1302823.

Gardinal, R., G. D. Calomeni, F. Zanferari, T. H. A. Vendramini, C. S. Takiya, H. G. Bertagnon, C. F. Batista, A. M. M. P. Della Libera, and F. P. Renno. 2018. Different durations of whole raw soybean supplementation during the prepartum period: Measures of cellular immune function in transition cows. J. Dairy Sci. 101:661-674. https://doi.org/10.3168/jds.2016-12168.

Grammatikos, S. I., P. V. Subbaiah, T. A. Victor, and W. M. Miller. 1994. Diverse effects of essential (n-6 and n-3) fatty acids on cultured cells. Cytotechnology 15:31-50.

Hobson, P. N., and C. S. Stewart. 2012. The Rumen Microbial Ecosystem. Springer Sci. Bus. Media, New York, NY.

Ireland, J. J. 1987. Control of follicular growth and development. J. Reprod. Fertil. Suppl. 34:39-54.

Khurana, N. K., and H. Niemann. 2000. Effects of oocyte quality, oxygen tension, embryo density, cumulus cells and energy substrates on cleavage and morula/blastocyst formation of bovine embryos. Theriogenology 54:741-756.

Kramer, J. K. G., V. Fellner, M. E. R. Dugan, F. D. Sauer, M. M. Mossoba, and M. P. Yurawec. 1997. Evaluating acid and base catalysts in the methylation of milk and rumen fatty acids with special emphasis on conjugated dienes and total trans fatty acids. Lipids 32:1219-1228.

Leury, B. J., L. H. Baumgard, S. S. Block, N. Segoale, R. A. Ehrhardt, R. P. Rhoads, D. E. Bauman, A. W. Bell, and Y. R. Boisclair. 2003. Effect of insulin and growth hormone on plasma leptin in periparturient dairy cows. Am. J. Physiol. Regul. Integr. Comp. Physiol. 285:R1107-R1115.

Lock, A. L., and D. E. Bauman. 2004. Modifying milk fat composition of dairy cows to enhance fatty acids beneficial to human health. Lipids 39:1197-1206.

McArt, J. A. A., D. V. Nydam, and G. R. Oetzel. 2012. Epidemiology of subclinical ketosis in early lactation dairy cattle. J. Dairy Sci. 95:5056-5066.

NRC. 2001. Nutrient Requirements of Dairy Cattle. 7th rev. ed. Natl. Acad. Press, Washington, DC.

Naves, A. B., J. E. Freitas Jr., R. V. Barletta, J. R. Gandra, G. D. Calomeni, R. Gardinal, C. S. Takiya, T. H. A. Vendramini, R. D. Mingoti, and F. P. Rennó. 2016. Effect of raw soya bean particle size on productive performance and digestion of dairy cows. J. Anim. Physiol. Anim. Nutr. (Berl.) 100:778-788.

Noble, R. C. 1981. Digestion, transport and absorption of lipids. Pages 57-93 in Lipid Metabolism in Ruminant Animals. W. W. Christie, ed. Pergamon Press Ltd., Oxford, UK.

Nocek, J. E. 1988. In situ and other methods to estimate ruminal protein and energy digestibility. A review. J. Dairy Sci. 71:2051-2069.

Nogalski, Z., M. Wronski, M. Sobezuk-Szul, M. Mochol, and P. Pogorzelska. 2012. The effect of body energy reserve mobilization on the fatty acid profile of milk in high-yielding cows. Asian-Australas. J. Anim. Sci. 25:1712-1720.

Oldick, B. S., and J. L. Firkins. 2000. Effects of degree of fat saturation on fiber digestion and microbial protein synthesis when diets are fed twelve times daily. J. Anim. Sci. 78:2412-2420.

Palmquist, D. L., and W. R. S. Mattos. 2006. Metabolismo de lipídeos. Pages 287-310 in Nutrição de Ruminantes. T. T. Berchielli, A. V. Pires, and S. G. Oliveira, ed. Funep, Jaboticabal, SP, Brazil.

Ponter, A. A., C. Guyader-Joly, F. Nuttincka, B. Grimarda, and P. Humblot. 2012. Oocyte and embryo production and quality after OPU-IVF in dairy heifers given diets varying in their n-6/n-3 fatty acid ratio. Theriogenology 78:632-645.

Pontes, J. H. F., F. A. Melo Sterza, A. C. Basso, C. R. Ferreira, B. V. Sanches, K. C. P. Rubin, and M. M. Seneda. 2011. Ovum pick-up, in vitro embryo production, and pregnancy rates from a large-scale commercial program using Nellore cattle (Bos indicus) donors. Theriogenology 75:1640-1646. 
Pontes, J. H. F., I. Nonato-Júnior, B. V. Sanches, J. C. Ereno-Junior, S. Uvo, R. R. Barreiros, J. A. Oliveira, J. F. Hasler, and M. M. Seneda. 2009. Comparison of embryo yield and pregnancy rate between in vivo and in vitro methods in the same Nelore (Bos indicus) donor cows. Theriogenology 71:690-697.

Santos, J. E. P., T. R. Bilby, W. W. Thatcher, C. R. Staples, and F. T. Silvestre. 2008. Long chain fatty acids of diet as factors influencing reproduction in cattle. Reprod. Domest. Anim. 43:23-30.

Staples, C. R., J. M. Burke, and W. W. Thatcher. 1998. Influence of supplemental fats on reproductive tissues and performance of lactating cows. J. Dairy Sci. 81:856-871.

Storry, J. E., P. E. Brumby, B. Tuckley, V. A. Welch, D. Stead, and R. J. Fulford. 1980. Effect of feeding protected lipid to dairy cows in early lactation on the composition of blood lipoproteins and secretion of fatty acids in milk. J. Agric. Sci. 94:503-516.

Sukhija, O. S., and D. L. Palmquist. 1988. Rapid method for determination of total fatty-acid content and composition of feedstuffs and feces. J. Agric. Food Chem. 36:1202-1206.

Van Soest, P. J., J. B. Robertson, and B. A. Lewis. 1991. Methods of dietary fiber, neutral detergent fiber, and nonstarch polysaccharides in relation to animal nutrition. J. Dairy Sci. 74:3583-3597.

Venturelli, B. C., J. E. Freitas Jr., C. S. Takiya, A. P. C. de Araujo, M. C. B. Santos, G. D. Calomeni, R. Gardinal, T. H. A. Vendramini, and F. P. Rennó. 2015. Total tract nutrient digestion and milk fatty acid profile of dairy cows fed diets containing different levels of whole raw soyabeans. J. Anim. Physiol. Anim. Nutr. (Berl.) 99:1149-1160.

Walsh, S. W., E. J. Williams, and A. C. O. Evans. 2011. A review of the causes of poor fertility in high milk producing dairy cows. Anim. Reprod. Sci. 123:127-138.

Weiss, W. P., H. R. Conrad, and N. R. St. Pierre. 1992. A theoretically based model for predicting total digestible nutrient values of forages and concentrates. Anim. Feed Sci. Technol. 39:95-110.

Widdas, W. F. 1988. Old and new concepts of the membrane transport for glucose in cells. Biochim. Biophys. Acta 947:385-404.

Wonnacott, K. E., W. Y. Kwong, J. Hughes, A. M. Salter, R. G. Lea, P. C. Garnsworthy, and K. D. Sinclair. 2010. Dietary omega-3 and -6 polyunsaturated fatty acids affect the composition and the development of sheep granulosa cells, oocytes and embryos. Reproduction 139:57-69.

Wright, J. 1998. Photomicrographic illustration of embryo codes. Pages 161-170 in Manual of the International Embryo Transfer Society. D. A. Stringfellow and S. M. Seidel, ed. Int. Embryo Transfer Soc., Champaign, IL.

Zachut, M., A. Arieli, H. Lehrer, N. Argov, and U. Moallem. 2008. Dietary unsaturated fatty acids influence preovulatory follicle characteristics in dairy cows. Reproduction 135:683-692. 